\title{
The Effect of Job Design, Cohesiveness, and Stress to Work Effectiveness of Teachers at PAUD Koja Sub District North Jakarta
}

\author{
Rita Rosmala $^{1^{*}} \quad$ Mukhneri Mukhtar $^{2} \quad$ Rugaiyah $^{3}$ \\ 1.School of Management, University State of Jakarta, Indonesia \\ 2.Lecture School of Management, University State of Jakarta, Indonesia
}

\begin{abstract}
The objective of this research was to determine the effect ofjob design, cohesiveness, and stress to work effectiveness of teacher PAUD at Koja Sub District, North Jakarta. The research was conducted by using a survey method with path analysis applied in testing hypothesis. The target population size of this research is 165 of teachers. Research samples selected as much as 117 teachers using simple random sampling technique. Based on this research of data obtained the following conclusions: (1) the job design has positive direct effect to work effectiveness, (2) the cohesivenessh aspositive direct effect towork effectiveness, (3) stress has negative direct effect to work effectiveness, (4) the job design has negative direct effect to stress, (5) cohesiveness have positive direct effect to stress. The conclusion is that the teacher's work effectiveness is effected by the job design, cohesiveness, and teacher's stress.
\end{abstract}

Keywords: Work effectiveness, job design, cohesiveness, and stress

DOI: $10.7176 / \mathrm{JEP} / 10-18-20$

Publication date:June $30^{\text {th }} 2019$

\section{Introduction}

The new paradigm for the management of early childhood education that has been proclaimed by the government is to make early childhood education have the right to Job Design to carry out its functions independently, as long as it does not conflict with applicable regulations. The existence of the teacher's role and function is very significant. Teachers are an important part of the teaching and learning process, both in formal, informal and non-formal education. Therefore, in everything related to their existence.

Giving great attention to early childhood education, especially about the development and growth of children is the responsibility of all of us both parents, government and stakeholders. Early childhood education has the main function of developing all aspects of child development, which include cognitive development, language, physical (gross and fine motoric), social and emotional. Rapid technological developments influence children's development. Therefore, teachers of Early Childhood Education are asked to continue to improve their abilities through education and training so that their knowledge remains in line with the times. The Head of the Early Childhood and Non-Formal and Informal Education Division of the DKI Jakarta Education Office, Uripasih said, the development of Kindergarten teachers, Quran Education Park, was continuously increased by the DKI Provincial Government. The goal is that they can keep up with the times and put it on their students. In Jakarta, there are currently 4,058 schools consisting of 2,018 TK, 2,000 PAUD and 40 TPA. Meanwhile, Chairman of the Jakarta Association of Kindergarten Organizing Organizations DKI Jakarta.

As for the problem, where a teacher often teaches not according to the program, which is not uncommon, it is not the core of his knowledge, things like this can of course lead to the learning process being not optimal. The number of teachers in Indonesia today is still lacking, if it is associated with the number of existing students. Therefore, the number of students per group with the number of teachers available at present is perceived to be less proportional, so it is not uncommon for one classroom / group to be often filled with more than 30 students. A number that is far from ideal for a learning and teaching process that is considered effective. Ideally, each class / group is filled with no more than 15-20 students to ensure the quality of the teaching and learning process that is maximal.

Improving teacher welfare that is reasonable, can improve teacher professionalism, including preventing teachers from experiencing stress in dealing with situations in an institution. To overcome the above problems, in general there are two solutions that can be given, namely: First, the systemic solution, namely the solution by changing social systems related to the education system. As is known, the education system is closely related to the economic system that is applied. The current education system in Indonesia, which has principles such as reducing the role and responsibility of the state in public affairs, including education funding. It will be very ineffective we apply a lesson with PAUD teachers who do not understand the role of a PAUD teacher. That the government will bear all state education funding.

Second, technical solutions, namely solutions that deal with technical matters that are directly related to education. This solution is for example to solve teacher quality problems. So, the solution to technical problems 
is returned to practical efforts to improve the quality of the education system. The low quality of teachers, for example, in addition to being given solutions to improving welfare, is also given a solution by financing teachers to continue to higher education, and provide various training to improve the quality of teachers. Low student achievement, for example, is given a solution by improving the quality and quantity of subject matter, improving teaching aids and educational facilities, and so on.

The management of good learning programs has an impact on the quality of early childhood education. With the work design of an ECD manager will improve the quality of early childhood education is the totality of circumstances and characteristics, input, process and educational products or services measured from a number of standards. So far, the management of early childhood education is based on Permendiknas No. 137 concerning the Standards of Early Childhood Education, an assessment to determine and reflect the quality of early childhood education needs to be done continuously strengthening the management of early childhood education. In addition, it is also necessary to evaluate the PAUD program to determine the quality status of PAUD development programs based on established quality standards.

A common desire to change management in early childhood education can be done, if PAUD managers are open and transparent, involving many parties and accommodating various interests in children's play activities. Without attitudes like this it will be difficult to change management in early childhood education. The teaching and learning process will be able to improve academic quality if the teaching staff has expertise in the field of science that he is practicing. Improving the quality of teaching staff in various levels, including training patterns and sharpening concept \& technical teaching knowledge is a requirement that must not be stopped. The arrangement and allocation of funds for the implementation of children's play activities with enjoyable learning must actually involve play-based learning activities that are transparant.

The third concept is succession. Succession is a stage where PAUD is able to take objective choices in the interests of the target students. Every decision made by PAUD Managers must have the substance of an academic decision, namely a decision-making process based on the communication process that refers to the dimension of value for the benefit of all PAUD citizens. in other words, if it is manifested into an academic frame of mind, the PAUD Manager's decision must reflect on the concept of PAUD insight, and moral considerations and the quality of education quality in the PAUD.

\section{Work Effectiveness}

The work effectiveness of the teacher becomes very important in achieving the goals of an organization. Reza Alami in his research journal stated that, If we review categories and criteria of effectiveness which are presented in the field of management, we understand that human resources management can directly or indirectly have a very important role in improving these indicators such as relocation or turnover of employees, employee absenteeism, compatibility of the norm and role, quality of product or production services, accidents, flexibility, adaptation for changing the standard operating procedures in response to environmental changes, Job satisfaction, employee motivation and staff morale. Work effectiveness is one of the cornerstones of productivity. Work performed poorly is both inefficient from the perspective of the appropriate utilization of resources, and ineffective in meeting the desired objectives. Inefficient and ineffective work practices normally reduce productivity and have a negative effect on employee morale, (Rao, 2003). work effectiveness is the behavioral outcome most closely associated with internal work motivation. Internal work motivation is a feeling of selfreward from doing job it self, (Compoux, 2011). Mathis said, "effectiveness for organizations is a measure of the ability of a program, project, or task to produce a specific desired effect or result that can be measured", (Mathis, 2014). High work effectiveness will be achieved if the rules that have been established by an organization can be done well, and effect by:

\subsection{Job Design}

One of the factors that is the achievement of teacher work effectiveness is work design. Work design that has been planned by the leader will determine the high and low effectiveness of work from a job. Teachers who are not satisfied with the unequal division of labor, division of tasks that are not in accordance with the capabilities, as well as the division of tasks disproportionate create the perception of inner teacher that inequality in the division of tasks. If this is not considered as a problem, it can cause problems for the organization. It was also stated by Erez Miriam that, job design the structure, content, and configuration of a person 's work tasks and roles is the direct representation of the person' s work environment. As such, it has an immediate influence on the situation as facilitating or inhibiting the opportunity to experience self-worth and well-being. Work design, structure, content, and task configuration and the work role of a person is a direct representation of the person's work environment. Thus, it has a direct influence on the individual's perception of the situation as a determinant of success. job desain is prosess of assigning task to a job, including the interdependencu of those task with other job. A job is a set of task performed by one person, (McShane, 2011). research in job design suggests the way the elements in a job are organized can act to increase or decrease effort and also suggests what those elements 
are, (Robbins, 2011). Job design refers to the process by which managers decide individual job tasks and authority. Apart from the very practical issues associated with job design, we can appreciate its importance in social and phychological terms. Jobs can sources of phychological stress and even mental and physical impairment. On a more positive note, jobs can provide income, meaningful life experiences, self-esteem, regulation of our lives, and respect from association with others, (Gibson, 2006). Job design is the application of motivational theories to the structure of work for improving productivity and satisfaction. Approaches to job design are generally classified as job simplification, job rotation, job enlargement, and job enrichment, (Richard, 2010).

\subsection{Cohesiveness}

Another factor is group cohesiveness. In an organization it is not surprising that a working group is found. This can have a positive impact when the group produces good cohesiveness that results in a better job. The cohesiveness of groups in an organization will make individuals more comfortable working, and get many friends. Individuals will become motivated if a co-worker can help the employee's work, if they find a problem. Adeleke also stated this in his research, "evaluating the impact of size on cohesion in different settings and contexts results in divergent outcomes, this variable is critical and one of the most influential variables in determining the structure and motivation levels in groups". Evaluating the impact of group cohesiveness in an organization will produce different results. The cohesiveness of this group is very important and is one of the most influential variables in determining the level of motivation in a group, as well as the level of achievement of work effectiveness of an employee. The same thing was stated by Munshid in his research that, "defined cohesion as a dynamic process which is reflected in the tendency for a group to stick together and remain united in the pursuit of its goals and objectives". Munshid expressed group cohesiveness as a dynamic process that was reflected in the group's tendency to stay together and remain united in pursuing its goals. Cohesiveness is a process whereby "a sense of 'we-ness' emerges to transcend individual differences and motives. Member of a cohesive group stick together. They are reluctant to leave the group. Cohesive group members stick together for one or both of the following reasons: (1) because they enjoy each others company or (2) because they need each other to accomplish a common goal, (Kreitner, 2010). Cohesiveness is the strength of the members desire to remain in a team and their commitment to it. Cohesiveness is influenced by the degree of compatibility between team goals and individual members' goals. Members who have strong desire to remain in a team and personally accept its goals form a highly cohesive team, (Slocum, 2007). Cohesiveness refers to the degree to which members are attracted to the team and to its members, and how loyal team members are to the team and to each other. Members of a highly cohesive team are motivated to stay in the team, contribute as much as they can, and conformt team norms. Because members of teams that lack cohesiveness are not strongly committed to the team or its goals and do not contribute to their full potential, team performance performance is compromised, (Phillip, 2012). Cohesiveness is the degree to which members are attracted to each other and are motivated to stay in the group. For instance, some work groups are cohesive because the members have spent a great deal of time together, or the group's small size facilitates high interaction, or the group has experienced external threats that have brought members close together, (Robbins, 2009). Cohesiveness is generally regarded as a force acting on the members to remain in a group that is greater than the forces pulling the member away from the group. Joining a group allows an individual to have a sense of belonging and feelings of morale. A cohesive group, then, involves individuals who are attracted to one another, (Gibson, 2006).

\subsection{Stress}

Other factors that influence work effectiveness are stress. In preliminary observations, researchers have observed that stress is another factor that influences the work effectiveness of teachers. As stated by Greenberg in Moaz Nagib's research, stress is a status which happens when individuals recognize that conditions or strains facing them may be more than their endurance. The term stress can be defined as a group of external harmful factors in the work environment, which may be psychological, physical or social. Stress is a condition that occurs when individuals recognize that the conditions faced are more than their endurance. Stress is an adaptive response to a situation that is perceived as challenging or threatening to a person's well-being. The stress response is a complex emotion that produces physiological changes to prepare us for "fight or flight" to defend ourselves from the threat or flee from it, (McShane:2008). Stress is the excitement, feeling of anxiety, and/or physical tension that occurs when the demands placed on an individual are thought to exceed the person's ability to cope. This most common view of stress is often called distress or negative stress. Stressors are the psychological demands in the environtment that cause this condition. They can take various forms, but all stressors have one thing in common: They create stress or the potential for stress when an individual perceives them as representing a demand that exceeds that person's ability to respond, (Slocum, 2007). Defined teacher stress as a response to negative effect such as anger or depression by a teacher, usually accompanied by potentially pathogenic, physiological and biochemical changes resulting from the aspects of the teacher's job and mediated by the 
perception that the demands made upon the teacher constituted a threat to his or her self-esteem or well being and by coping mechanisms activated to reduce the perceived threat, (Florence, 2015).

There is an effect of work design on work effectiveness, "in general, managers try to design jobs to motivate employees to perform well, enjoy their work, and receive the outcomes of their deserve. Job design also influences the motivation of employees and their input levels. When employees are motivated to input at high levels (to work harder, more efficient, and more creatively), and perform their jobs more effectively, organizational effectiveness increases, (Jennifer, 2012).

The effect of group cohesiveness on work effectiveness as follows: Members of a high morale group are more likely to think of themselves as a group and work together effectively. Strong and cohesive work groups can, therefor, have the beneficial effects for the organization. Compact group membership can experience that is beneficial to each individual, can contribute to moral improvement and can help increase creativity. Group members who have high morals are more likely to think of themselves as a group and work together effectively, (Mullins, 2010).

The effect of stress on work effectiveness, "job management is to identify the cause of organizational, group and individual effectiveness. The distinction between causes of effectiveness and the indicators of effectiveness can be difficult for both managers and researchers, (Gibson, 2006).

\section{Methodology}

This quantitative research uses survey method through Path Analysis approach. The instrument used in all questionnaire-shaped variables. Before being used in the study, the instrument was tested to test the validation and reliability of each instrument so that it could be used in the study. The study was conducted on 117 PAUD teachers in Koja Sub-Sub District, North Jakarta. The number of teachers as many as 165 teachers and sampling using the Slovin formula. A total of 117 teachers were obtained by simple random method from the population and spread to all PAUD in Koja Sub District, North Jakarta.

The data in this study were concluded by using questionnaires which included questionnaires on work effectiveness, work design, and stress, which had gone through the stages of empirical validation through instrument testing. Furthermore, the calculation of reliability on valid instrument items that show the feasibility of the instrument to be used in the research is carried out. Validation test results and instrument reliability calculations are as follows: (1) work effectiveness questionnaire, validation $=94.28 \%$, reliability $=0.958,(2)$ work design questionnaire, validation $=88.57 \%$, reliability $=0.966$, (3) questionnaire group compactness, validation $=88.57 \%$, reliability $=0.973$, (4) stress questionnaire, validation $=91.43 \%$, reliability $=0.946$. So it is concluded that all valid instrument items are reliable instruments.

Analysis of research data was analyzed using descriptive analysis and inferential analysis with a path analysis approach. Descriptive analysis is done by calculating the average value, median, mode, variance, and standard deviation. The data characters of each variable are displayed in the frequency distribution table and histogram. Inferential analysis is preceded by an analysis of the requirements test, consisting of an estimated error normality test, a significance test, and a linearity test.

\section{Result and Discussion}

Data analysis to test the research hypothesis is carried out by statistical analysis or path analysis. Before testing the hypothesis first, the analysis of the requirements analysis is carried out which includes the following: (1) testing the estimated normality error, and (2) the significance test and regression linearity.

Test the estimated normality error using the liliefors test. The test criteria is if Lcounts $<$ Ltable at $\alpha=0.05$, then the regression equation is normally distributed. Based on the calculation of the X4 error estimation normality test for X1, X4 for X2, X4 for X3, X3 for X1, X3 for X2, all of them indicate that L counts $<\mathrm{L}$ table so that all regression equations are normally distributed.

For the significance test carried out by ANAVA calculation with the test criteria is if $\mathrm{F}$ count $>\mathrm{F}$ table at $\alpha=$ 0.01 then the regression coefficient between variables is significant. Based on the results of the calculation of the significance test X4 for X1, X4 for X2, X4 for X3, X3 for X1, and X3 for X2, all of them indicate that F count> $\mathrm{F}$ table, the regression coefficient between all variables is very significant. To test linearity of simple regression equations with criteria that if $\mathrm{F}$ counts $<\mathrm{F}$ table then the relationship between variables is linear. Based on the calculation of the X4 linearity test for X1, X4 for X2, X4 for X3, X3 for X1, X3 for X2, all of them show that F counts $<\mathrm{F}$ table, so all relationships between variables are linear.

After testing the estimated normality error, significance test and regression linearity, path analysis is conducted to test the research hypothesis. The following table describes the results of the calculation and path coefficient testing with $\mathrm{t}$ table $=1.658$ for $\alpha=0.05$ with the criteria if $\mathrm{t}$ count $>$ from $\mathrm{t}$ table then the path coefficient test results show that the path is very good and can explain the influence between variables. 
Table 1. The Result of Validity Test and Reliability Calculation of All Variables

\begin{tabular}{ccccc}
\hline Variables & $\begin{array}{c}\text { Number of Sample } \\
(\mathrm{N})\end{array}$ & Number of Valid Items & Alpha Values & Remarks \\
\hline Work Effectiveness & 35 & 33 & 0.958 & Reliable \\
Job Design & 35 & 31 & 0.966 & Reliable \\
Cohesiveness & 35 & 31 & 0.973 & Reliable \\
Stress & 35 & 32 & 0.946 & Reliable \\
\hline
\end{tabular}

Tabel 2. Results and Path Coefficient Testing

\begin{tabular}{cccc}
\hline Jalur & Koefisien Korelasi & Koefisien Jalur & $\mathrm{t}_{\text {hitung }}$ \\
\hline $\mathrm{X}_{1}$ terhadap $\mathrm{X}_{4}$ & $\mathrm{r}_{14}=0,573$ & $\mathrm{p}_{41}=0,389$ & 4,990 \\
\hline $\mathrm{X}_{2}$ terhadap $\mathrm{X}_{4}$ & $\mathrm{r}_{24}=0,575$ & $\mathrm{p}_{42}=0,386$ & 4,821 \\
\hline $\mathrm{X}_{3}$ terhadap $\mathrm{X}_{4}$ & $\mathrm{r}_{34}=-0,254$ & $\mathrm{p}_{43}=-0,047$ & $-0,636$ \\
\hline $\mathrm{X}_{1}$ terhadap $\mathrm{X}_{3}$ & $\mathrm{r}_{13}=-0,223$ & $\mathrm{p}_{31}=-0,104$ & $-1,046$ \\
\hline $\mathrm{X}_{2}$ terhadap $\mathrm{X}_{3}$ & $\mathrm{r}_{23}=-0,313$ & $\mathrm{p}_{32}=-0,266$ & $-2,686$ \\
\hline
\end{tabular}

Thus, it can be concluded that the path between work design variables on work effectiveness, group cohesiveness on work effectiveness, and stress on work effectiveness, work design on stress, and group cohesiveness on stress, has significant path coefficients because the $t$ count $>t$ table. The path coefficient test results in this study indicate that the path is very good and can explain the effect of work design, group cohesiveness, and stress on the effectiveness of PAUD teachers in Koja Sub District, North Jakarta. So that it can explain the effect of exogenous variables with the endogenous variables analyzed.

The results of the study mean that generally in PAUD teachers in Koja Sub-Sub District, North Jakarta there are two positive direct effects: (1) work design on work effectiveness, (2) group cohesiveness on work effectiveness, and there are three negative direct effects, namely; (1) stress on work effectiveness, (2) work design on stress, (3) group cohesiveness towards stress. In detail the discussion of the results of the analysis and testing of the research hypothesis is described as follows:

Table 3. Recapitulation of the Result of Hypothesis Test

\begin{tabular}{|c|c|c|c|c|c|}
\hline No & Hypothesis & Statistic Test & Decision & Conc & Ision \\
\hline 1 & $\begin{array}{l}\text { Job Design directly influences } \\
\text { Work Effectiveness positively }\end{array}$ & $\begin{array}{l}\mathrm{H}_{0}: \beta_{41} \leq 0 \\
\mathrm{H}_{1}: \beta_{41}>0\end{array}$ & $\mathrm{H}_{0}$ was rejected & $\begin{array}{l}\text { Direct } \\
\text { influence }\end{array}$ & positive \\
\hline 2 & $\begin{array}{l}\text { Cohesiveness directly influences } \\
\text { Work Effectiveness positively }\end{array}$ & $\begin{array}{l}\mathrm{H}_{0}: \beta_{42} \leq 0 \\
\mathrm{H}_{1}: \beta_{42}>0\end{array}$ & $\mathrm{H}_{0}$ was rejected & $\begin{array}{l}\text { Direct } \\
\text { influence }\end{array}$ & positive \\
\hline 3 & $\begin{array}{l}\text { Stress directly influences Work } \\
\text { Effectiveness negatively }\end{array}$ & $\begin{array}{l}\mathrm{H}_{0}: \beta_{43} \geq 0 \\
\mathrm{H}_{1}: \beta_{43}<0\end{array}$ & $\mathrm{H}_{0}$ was rejected & $\begin{array}{l}\text { Direct } \\
\text { influence }\end{array}$ & negative \\
\hline 4 & $\begin{array}{l}\text { Job Design directly influences } \\
\text { Stress negatively }\end{array}$ & $\begin{array}{l}\mathrm{H}_{0}: \beta_{31} \geq 0 \\
\mathrm{H}_{1}: \beta_{31}<0\end{array}$ & $\mathrm{H}_{0}$ was rejected & $\begin{array}{l}\text { Direct } \\
\text { influence }\end{array}$ & negative \\
\hline 5 & $\begin{array}{l}\text { Cohesiveness directly influences } \\
\text { Stress negatively }\end{array}$ & $\begin{array}{l}\mathrm{H}_{0}: \beta_{32} \geq 0 \\
\mathrm{H}_{1}: \beta_{32}<0\end{array}$ & $\mathrm{H}_{0}$ was rejected & $\begin{array}{l}\text { Direct } \\
\text { influence }\end{array}$ & negative \\
\hline
\end{tabular}

\section{Conclusion}

Based on the results of testing hypotheses and discussion of the results of research that have been stated in the previous chapter, through research conducted on PAUD teachers in the Koja Sub District of North Jakarta obtained the following conclusions: (1) job design has a direct positive effect on the effectiveness of PAUD teacher work in the Sub District Koja North Jakarta. This means that the right job design will cause a high increase in work effectiveness; (2) cohesiveness has a direct positive effect on the effectiveness of PAUD teachers in Koja Sub District, North Jakarta. This means that an increase in good cohesiveness will lead to a high increase in work effectiveness; (3) Stress has a direct negative effect on the effectiveness of PAUD teacher work in Koja Sub District, North Jakarta. This means that a decrease in stress will cause a high increase in work effectiveness; (4) job design has a direct negative effect on the stress of PAUD teachers in Koja Sub District, North Jakarta. This means that the right job design will cause a decrease in stress levels; (5) cohesiveness has a direct negative effect on the stress of PAUD teachers in Koja Sub District, North Jakarta.

This means that increasing the cohesiveness of a good group will cause a decrease in the level of stress. Based on the research findings above, it can be stated that work effectiveness can be influenced by job design variables, cohesiveness, and stress. However, other variables still need attention in advanced research related to work effectiveness variables. Based on the conclusion of this study shows that in improving the work effectiveness of teachers can be done by improving job design, cohesiveness, and decreasing the level of stress in the teacher. 


\section{References}

Colquitt, LePine, Wesson, Organizational Behavior, Improving Performance and Commitment in the Workplace, Second Edition, New York : McGraw-Hill: 2011

Champoux Joseph. E, Organizational Behavior: Integrating Individuals, groups and organizations, New York: West Publishing Company. 2011

Florence A.Yusuf, et al, Causes and impact of Stress on Teacher's Productivity as Expressed by Primary School Teachers in Nigeria, Creative Education, 2015

Gibson, Ivancevich, Donnelly, Konopaske, Organizations, Behavior Structure Processes, New York, McGrawHill: 2006

Jennifer M.george, Gareth Jones, Understanding and Managing Organizational Behavior, Sixth Edition ,New Jersey : Pearson, 2012

John W. Slocum,Jr, Don Hellriegel, Fundamentals of Organizational Behavior, USA: Thomson Shout Western, 2007

John W. Newstrom, Organizational Behavior: Human Behavior at Work, New York: International Edition; McGraw-Hill/Irwin, 2007

Kreitner, Kinicki, Organizational Behavior, New York: McGraw-Hill, 2010

McShane, Von Glinow, Organizational Behavior, Fourth Edition, New York, Mc Graw-Hill: 2008

Mullins, Laurie, Management \& Organizational Behavior, London: Pearson, 2010

Phillips, Gully, Organizational Behavior, Toos for Success, United State of America, South-Western Cengage Learning: 2012

Rao, Computer Education, New Delhi: Efficient Offset Printers, 2003

Richard L. Daft, New Era Of Management, 10th Edition, China, South-Western Cengage Learning: 2012

Robert L. Mathis, Jhon H.Jackson, Sean R. Valentine, Human Resource Management, Fourteenth Edition, Canada: Cengage Learnin, 2014

Stephen P.Robbins, Timothy A.Judge, Organizational Behavior, New Jersey: Pearson, 2009

Stephen P.Robbins, Timothy A.Judge, Organizational Behavior, New Jersey: Pearson, 2011 